\title{
Comparative Translation, from English into Albanian of 'Episode 11, Sirens, in Ulysses', by James Joyce
}

\author{
Rozana Bela \\ University of Tirana \\ E-mail:belarozana@yahoo.com
}

\section{Doi:10.5901/ajis.2012.v2n4p39}

\begin{abstract}
:
In this paper we will give a study of Episode 11, "Sirens" in "Ulysses", by James Joyce. Through comparative translation from English into Albanian of the novel, based on the literary explication, we will answer such questions as "How are the logical connections organized?", "How are the logical connections in syntactycal systems factorized?", and "How are the logical connections realized in the form of a text?". We will emphasize the nature of: the cognitive meaning and the way it has been expressed; interactive meaning and its expression through the system of states, and the meaning of the discourse and its expression through the system of topics. We will make use of analytical approach and comparative approach. The analytical approach will be realized through the deep and detailed examples provided by the source text and target text, in order to define the translator's strategies, which have made possible the construction of the translation model. In addition, the comparative method will be used to penetrate the core of the two planes of defects: language texts as a whole, and texts as a reflection of culture. Consequently, we will see the differences between the two linguistic codes (Albanian-English) and the embodiment of their respective cultures.
\end{abstract}

Key words: English-Albanian Translation, Ulysses, Episode 11, Sirens, Translation Procedures.

\section{"Sirens" Summary}

This episode analyses several of the major themes of Ulysses, such as sexual temptation and Bloom's isolated social status, through the lens of music. The reader first meets music in this episode in the voices of the barmaids, associated with Bloom's book The Sweets of Sin, which is placed in their conversation in the text:

"By went his eyes. The sweets of sin. Sweet are the sweets. Of sin. In a giggling peal young goldbronze voices blended, Douce with Kennedy your other eye. They threw young heads back, ...high piercing notes. Ah, panting, sighing, sighing, ah, foredone, their mirth died down." (Joyce 156-162)

The first sort of music Joyce gives us are the "high piercing notes" of the barmaids' laughter. Immediately, the girls are associated with the Sirens' allure, and the structure of their "song" here makes it clear that they are a pair associated with sex. While Bloom with his salacious novel has yet to make his entrance in the bar, the juxtapositioning of "the sweets of sin" with such suggestive descriptions ("threw young heads back", "panting, sighing, sighing, ah, foredone") seems to align their song with sex, and the allure of possible outlets for sexual distraction on the pathway home. This theme is repeated several times throughout the episode, with each reincarnation of temptation becoming less and less attractive to Bloom, ending with the "frowsy whore" (Joyce, Ulysses) at the end of the episode. But despite all this temptation, Bloom knows that he is "dear too near to home sweet home" (Joyce, Ulysses) and is able to resist the sexual allure of the many sirens in this episode, though he will later fall prey to Gerty's visual allure in Episode 13.

While to some extent his resistance is based upon his constant thoughts back to Molly in this episode, the real deterrent keeping Bloom from the Sirens is his impotence in this episode. Bloom is plagued by the inability to act in this episode; he is defined by acts that he cannot do, such as enter the bar when Boylan is 
inside, sing, or write a letter to Martha. On a linguistic level, he is unable to finish his words, such as in the text of his letter to Martha, "got your lett and flow. Hell did I put? Some pock or oth. It is utterly imposs. Underline imposs. To write today" (Joyce, Ulysses). Bloom seems unable to complete even the most basic of sentences; his writing is fragmented, and cannot be pieced back together.

Unfortunately, the reassembly of fragments seems to be just what Bloom desires, given the appearance of "Siopold!" at the climax of Lionel's song (Joyce, Ulysses).). The lines before seem to describe the transcendence of music; Bloom's description becomes completely ecstatic, carried by the "high vast irradiation everywhere all soaring all around about the all, the endlessnessnessness..." (Joyce, Ulysses).). The power of music seems to be in lowering the boundaries between self and others, suggested by Bloom's long string of ambiguous personal pronouns, "she out to. Come. To me, to him, to her, you too, me, us" (Joyce, Ulysses).). Bloom's ecstatic moment here, rather than the sexual release offered throughout the female figures in the episode, is the joy of becoming part of an "us," of leaving behind his isolation and joining a community. But though music seems an excellent vehicle for this desire, it only serves to further portray his isolated status, as he must watch all of this music from the other room. He sits with Goulding and eats, "married in silence" (Ulysses).), denied any of the emotional release that the other men get from the songs. Thus, Bloom is set up in opposition to the social and emotional benefits of music, made clear by one of the examples of counterpoint on his way out:

\author{
"Bless me father, Dollard the croppy cried. Bless me and let me go. \\ Tap. \\ Bloom looked, unblessed to go." (Joyce, Ulysses).
}

By sharing an opposing adjective pair, bless-unblessed, Bloom counters the croppy boy in much the same way he does Boylan. "The Croppy Boy," a song about a young Irish rebel begging his priest for forgiveness, thus becomes another figure that Bloom fails to live up to. Unblessed and unconquered, Bloom remains decidedly apart from his Irish companions at the bar and unable to compete with Boylan's sexual power. But perhaps, despite his musical impotence, Bloom takes revenge on it at the end of the episode, when the final note, so to speak, of Joyce's musical fugue is the passing of gas.

\title{
Translation procedures, strategies and methods used in translating "Sirens"
}

Translation has been used to bring written or spoken SL (source language) texts to equivalent written or spoken TL (target language) texts. One of the major purposes of translation is to transfer and reproduce various religious, literary, scientific, and philosophical texts in another language, making them available to wider readers.

Although translating is an ancient practice, it is only less than thirty years that it has been formally and systematically studied in a non-evaluative way. André Lefevere, a well-known expert in translation, proposed to adopt the expression Translation Studies to refer to the discipline pertaining to the issues of the production and description of translations (Bassnet 1991) in 1978, at a symposium on literature and translation.

However this does not mean that theories did not exist before this date or that the end products of this practice were not analyzed. They were realized in pedagogic perspective and evaluative perspective.

On the other hand if language were just a classification for a set of general or universal concepts, it would be easy to translate from a source language to a target language; furthermore, under the circumstances the process of learning a second language would be much easier than it actually is. According to Culler (1976), languages are not nomenclatures and the concepts of one language may differ radically from those of another, since each language articulates or organizes the world differently, and languages do not simply name categories; they articulate their own (Culler, 1976 p.21-2). What Culler (1976), writes is that one of the troublesome problems of translation is the disparity among languages. The bigger the gap between the SL and the $T L$, the more difficult the transfer of message from the former to the latter will be. The difference 
between an SL text and a TL text and the variation in their cultural background make the process of translating a real challenge.

The translator Idlir Hazizi has made use of technical and organizational procedures while translating "Ulysses". As far as technical procedures are concerned we can mention the following steps as depicted by Nida (1964):

a. analysis of the source and target languages;

b. a through study of the source language text before making attempts translate it;

c. Making judgments of the semantic and syntactic approximations. (Nida, E. A. 1964,pp.241-45).

Undergoing the techinal procedures is in a way or another obligatory to any translator as they have to know very good both the source and target languages. A translator must study thoroughly both languages and has to make judgements of the semantic and syntactic approximations otherwise the translation will not bring the message given in the SL to the target reader.

On the other hand knowing that Idlir Hazizi's translation of James Joyce's "Ulysses" is so far the only version in Albanian we can not tell for sure how the translator made use of the organizational procedures which according to Nida (1964) consist of :

"constant reevaluation of the attempt made; contrasting it with the existing available translations of the same text done by other translators, and checking the text's communicative effectiveness by asking the target language readers to evaluate its accuracy and effectiveness and studying their reactions (pp. 246-47)."

The translator has to have a strategy while translating and as Krings (1986:18) defines translation strategy as "translator's potentially conscious plans for solving concrete translation problems in the framework of a concrete translation task," (Krings, H.P. 1986).

Seguinot (1989) believes that there are at least three global strategies employed by the translators: (i) translating without interruption for as long as possible; and in our study has to do with the case of Penelope in Ulysses and typical in translating Joyce's works (ii) correcting surface errors immediately; (iii) leaving the monitoring for qualitative or stylistic errors in the text to the revision stage. (Seguinot, C. 1989).

Whereas Loescher (1991:8) defines translation strategy as "a potentially conscious procedure for solving a problem faced in translating a text, or any segment of it." The notion of consciousness is significant in distinguishing strategies which are used by the learners or translators. And the translator who would translate James Joyce's "Ulysses" has to strongly consider the technique of the stream of consciousness as typical of Joyce's style of writing. In this regard, Cohen (1998:4) asserts that "the element of consciousness is what distinguishes strategies from these processes that are not strategic.

According to Venuti (1998:240), translation strategies "involve the basic tasks of choosing the foreign text to be translated and developing a method to translate it." ${ }^{1}$ In this case he employs the concepts of domesticating and foreignizing to refer to translation strategies of which the translator has made use of while bringing the text to Albanian.

As Newmark would write: "while translation methods relate to whole texts, translation procedures are used for sentences and the smaller units of language" Newmark, P. (1988b, p.81). It is important to mention that the translator translated the eleventh part of the novel, "Sirens" by using the following methods of translation as depicted by Newmark:

a. Word-for-word translation: in which the SL word order is preserved and the words translated singly by their most common meanings, out of context.

b. Literal translation: in which the SL grammatical constructions are converted to their nearest TL equivalents, but the lexical words are again translated singly, out of context.

c. Faithful translation: it attempts to produce the precise contextual meaning of the original within the constraints of the TL grammatical structures. 
d. Semantic translation: which differs from 'faithful translation' only in as far as it must take more account of the aesthetic value of the SL text.

e. Adaptation: which is the freeest form of translation, and is used mainly for plays (comedies) and poetry; the themes, characters, plots are usually preserved, the SL culture is converted to the TL culture and the text is rewritten.

f. Free translation: it produces the TL text without the style, form, or content of the original.

g. Idiomatic translation: it reproduces the 'message' of the original but tends to distort nuances of meaning by preferring colloquialisms and idioms where these do not exist in the original.

Communicative translation: it attempts to render the exact contextual meaning of the original in such a way that both content and language are readily acceptable and comprehensible to the readership (Newmark 1988b: 45-47).

\section{Source Text (ST) English}

1. Bronze by gold heard the hoofirons, steelyringing Imperthnthn thnthnthn.

The last two groups of letters actually found in the very first sentence of the episode prepare the reader for a new style used in the episode compared to the rest of the novel, which is considered highly musical.

Target Text (TT) Albanian

E bronzta ndanë së artës ndjeu thundrat e hekurta, tingullçeliktat

Taturp, trp trp.

The same style has been preserved in the target text as well. It is to be noted howwever that the rules of the word formation in Albanian is strictly respected. Thus tingull çeliktat is composed of a noun and an adjective. Ebronzta ndanë së artes: in this case the translator has preserved the same word stucture as in the source text.

\section{Horrid! And gold flushed more (ST)}

E tmerrshme! Dhe e arta shkelqente më tepër. (TT)

The same situation regarding the structure of the sentence as in the previous example. There is the unit shift which has taken place in the taregt text with the unit "gold" which is translated "e arta" and in the target text it is the function of the noun derived from the adjective.

\section{A husky note blew (ST) - Një notë të ngjirur pipëze fryu. (TT)}

Blew. Blue bloom is on the. - Mbiu. Blu mbiu nëpër.

In this sentence the word "blew"is translated differently from the forecoming sentence and the translator is conditioned to do so because while translating we translate words realted to the context and not just word by word.

\section{Goldpinnacled hair (ST)}

Flokët e artë mbledhur majë kokës. (TT)

In this example the word "pinnacled" is translated through an explanation in the target text. I would suggest another translation for this word: "flokëartëtopuzmbledhur" in a signle word as it keeps the original style of the Joyce and it does not harm the target language.

\section{Jingle jingle jaunted jingling (ST)}

Çingli gingli gingli rrugëton çingël. (TT) 
In this case the music of the sentence is preserved although it is adopted in the target language. However the translator could have used the leter "xh" (dz) instead of the letter "ç". The sentence could have even been translated for what the source sentence means: "Tringëllima tringëllima rrugëtonte duke tringëllitur". And this translation does not lose or vain the main purpose of the style used in this episode: it's musicality. Maybe the translator has tried to be a bit shorter in choosing words as in the original text.

\section{Coin rang. Clock clacked (ST) Monedha kërciti. Sahati klithi (TT)}

The translator has preserved the same sentence structure from the dource text while translating it in Albanian which is Subject + Verb in both cases. The tense of the verbs, Simple Past Tense has not change in none of the respective sentence.

7. Boomed crashing chords. When love absorbs. War! War! The tympanum. (ST) Bum benë kordat në krisje. Kur dashuria thith. Luftë! Luftë! Timpani. (TT)

The translation of the "boomed crashing chords" could have been translated "buçiten kordat në krisje".

\section{Martha! Come!}

Marta! Ma jep, eja!

Ma jep in the target text is added in an extra way as it is not given in the source text explicitly. The reason is to imply some flirtation and sexual implication between the characters in the episode.

\section{Clapclap. Clipclap. Clappyclap. (ST)}

Traktrak. Triktrak. Truktrak. (TT)

The musicality goes on during the whole episode and there is only adoption regarding the words chosen to imitate the onomatopeic sounds.

10. Goodgod he nev erheard inall. (ST)

Zotnaruaj aikur respatidegjuar nëjetë (TT)

The style has been preserved as in the source text in order to make the description of the scene vivid and give some kind of musicality to what is happening.

\section{Deaf bald Pat brought pad knife took up. (ST)}

Shurdh tullaci Pat solli letër thikën mori. (TT)

The structure in the target text is preserved originally as in the source text and it is not natural for Albanian. The purpose of it is to just bring the style of the original source to the target reader. The lack of the punctuation marks is noted in both the source and target text.

12. I feel so sad. P.S. So lonely blooming. (ST)

Ndihem aq trishtë PS. Sa vetëm po sythoj. (TT)

The translator could have used the word "po lulezoj" instead of "po sythoj" as actually "blooming" is more than just "stitch" which would be the backtranslation for the word "sythoj". 
13. Smart Boylan bespoke potions. (ST)

Bojlani porositi helmet. (TT)

The trasnlator has not translated the word "smart". Just an omission of the word which actually is important as it describes Boylan. Apart of all of this the reader would understand if the description was a real quality of the character of just an irony towards him.

\section{Conclusions}

Generally speaking we can say that translating Joyce in general is a highly demanding work and the translator Idlir Azizi has completed it successfully. "Sirens" of Ulysses by James Joyce is a difficult translation to deal with as a translator has to translate made up words which actually are invented by Joyce and find the equivalence translation in Albanian. Thus the translator's duty becomes much more difficult than when translating a traditionally-structured piece of work. On the other hand the fact that the translator Azizi is a writer as well allows him to a certain degree to interfere while translating as far as literary creation is concerned. This "interference" is done in a way that it does not violent the original work of James Joyce and the message given in the source text is brought wisely to the target reader.

\section{References}

Joyce, James,. Ulysses. New York: Vintage International, 1990.

Newmark, Paul, A Textbook of Translation, London, Prentice Hall, 1988.

Snell-Hornby, Mary, Translation Studies. An Integrated Approach, Amsterdam, John Benjamins, 1988.

Toury, Gideon, Descriptive Translation Studies and Beyond, Amsterdam, John Benjamins,1995.

Venuti, Lawrence, Rethinking Translation. Discourse, Subjectivity, Ideology, London, Routledge, 1992. The Translator's Invisibility. A History of Translation, London, Routledge, 1995.

Susan BASSNETT, For a history of the discipline:, Translation Studies, London, Routledge, 1991.

Culler, J. (1976). Structuralist poetics: structuralism, linguistics, and the study of literature. Cornell: Cornell University Press.

Nida, E. A. (1964). Towards a science of translation, with special reference to principles and procedures involved in Bible translating. Leiden: Brill.

Krings, H.P. (1986). Translation problems and translation strategies of advanced German learners of French. In J. House, \& S. Blum-Kulka (Eds.), Interlingual and intercultural communication (pp. 263-75). Tubingen: Gunter Narr

Seguinot, C. (1989). The translation process. Toronto: H.G. Publications.

Cohen, A.D. (1984). On taking tests: what the students report. Language testing, 11 (1). 70-81.

Loescher, W. (1991). Translation performance, translation process and translation strategies. Tuebingen: Guten Narr.

Venuti, L. (1998). Strategies of translation. In M. Baker (Ed.), Encyclopedia of translation studies (pp. 240-244). London and New York: Routledge.

Newmark, P. (1988b). Approaches to Translation. Hertfordshire: Prentice Hall 